\title{
Ionically Bound Peroxidase from Peach Fruit
}

\author{
Valdir Augusto Neves \\ Department of Food Nutrition - Faculty of Pharmaceuticals Sciences - Universidade Paulista Julio de Mesquita \\ Filho - UNESP. Rodovia Araraquara-Jaú Km 1, Araraquara-SP, Brazil
}

\begin{abstract}
Soluble, ionically bound peroxidase (POD) and polyphenoloxidase (PPO) were extracted from the pulp of peach fruit during ripening at $20^{\circ} \mathrm{C}$. Ionically bound form was purified 6.1-fold by DEAE-cellulose and Sephadex G-100 chromatography. The purified enzyme showed only one peak of activity on Sephadex G-100 and PAGE revealed that the enzyme was purified by the procedures adopted. The purified enzyme showed a molecular weight of $29000 \mathrm{Da}$, maximum activity at $\mathrm{pH} 5.0$ and at $40^{\circ} \mathrm{C}$. The calculated apparent activation energy (Ea) for the reaction was $10.04 \mathrm{kcal} / \mathrm{mol}$. The enzyme was heat-labile in the temperature range of 60 to $75^{\circ} \mathrm{C}$ with a fast inactivation at $75^{\circ} \mathrm{C}$. Measurement of residual activity showed a stabilizing effect of sucrose at various temperature/sugar concentrations $(0,10,20 \%, w / w)$, with an activation energy (Ea) for inactivation increasing with sucrose concentration from 0 to $20 \%(w / w)$. The $\mathrm{Km}$ and $V_{\max }$ values were 9.35 and $15.38 \mathrm{mM}$ for $\mathrm{O}$-dianisidine and $\mathrm{H}_{2} \mathrm{O}_{2}$, respectively. The bound enzyme was inhibited competitively by ferulic, caffeic and protocatechuic acids with different values of $\mathrm{Ki}$,. L-cysteine, p-coumaric and indolacetic acid and $\mathrm{Fe}^{++}$also inhibited the enzyme but at a lower grade. Nethylmaleimide and $p C M B$ were not effective to inhibit the enzyme demonstrating the nonessentiality of SH groups.
\end{abstract}

Key words: Peach peroxidases, ripening, purification, kinetics, heat stability

\section{INTRODUCTION}

Peroxidase (E.C. 1.11.1.7) (POD) has been implicated in a variety of physiological process such as ethylene biogenesis, cell development, membrane integrity, response to injury, disease resistence (Abeles \& Biles, 1991, Gillikin \& Graham , 1991, Haard, 1977, Hammerschmidt et al., 1984, Vàmos-Vigyàzo, 1981). The properties of peroxidase and its physiological role in postharvest fruits and vegetables have been reviewed by several authors ( Haard, 1977, Gorin \& Heidema, 1976, Miesle et al., 1991, Rhotan \& Nicolas, 1989). The enzyme has been also involved in deteriorative changes in flavor, texture and color in raw and processed fruits and vegetables (Haard, 1973, Burnette, 1977, Clemente \& Pastore, 1998, Vàmos-Vigyàzo,
1981). Peroxidase activity has been investigated in a range of fruits including grape (Robinson et al., 1989), mangoes (Khan \& Robinson, 1993-a), papaya (Silva et al., 1990), pears (Moulding et al., 1989), oranges (Clemente, 1996), peaches (Lourenço \& Neves, 1997, Neves \& Lourenço, 1998) and apples (Moulding et al., 1987). The enzyme occurs in multiple molecular forms and is present in most fruits and vegetables in a soluble and bound (ionically and covalently) forms (Moulding et al., 1987, 1989, Robinson et al., 1989, Silva et al., 1990, Thomaz et al., 1981, Wang \& Lu, 1983), whose catalytic properties are influenced by variety or/and cultivar, growth and physiological stages. A correlation between peroxidase activity and fruit ripening has been shown in a number of cases (Flurkey \& Jen, 1978, Rhotan \& Nicolas, 1989, Silva et al., 1990, 
Thomaz et al., 1981). In mango (Khan \& Robinson, 1993) apples (Moulding et al., 1987) and papaya (Silva et al., 1990) peroxidase activity increases with ripening. The activity of bound and soluble enzymes isolated from the pulp of ripening banana fruit were increased at the onset of the respiration climateric (Haard, 1973). In contrast, the soluble peroxidase form from tomato (Kokkinakis \& Brooks, 1979) and papaya fruit (Silva et al, 1990) reach a maximum peak followed by a marked decrease at the initial levels.

The activity of the ionically bound peroxidase form from papaya was greatly increased with ripening but gradually fell as the fruit turned from ripe to over-ripe stage (Silva et al., 1990). It is generally accepted that peroxidase is the most heat-stable enzyme in vegetables and that under conditions of limited treatment, it can regain its activity during storage of processed foods (Burnette, 1977, Chang et al., 1988, Khan \& Robinson, 1993b, Clemente, 1996, Neves \& Lourenço, 1998). Polyhydric alcohols and sugars have been utilized as anti-denaturant agents against freeze and heat-induced denaturation in proteins (Arakawa \& Timashef, 1982, Lee \& Timashef, 1981, Chang et al., 1988) and in the fruit processing most of these compounds could be used. In contrast, the effects of these additives on thermal behaviour of the heat resistant enzymes related to off-flavors generation, as peroxidase and polyphenoloxidase, need to have better understanding. To our knowledge, the ionically bound peroxidase from peach fruit has not been adequately investigated. The present investigation was designed to study the extraction of soluble, ionically bound peroxidase and polyphenoloxidase from peach fruit and the changes in the enzyme activities during ripening. Procedures for purifying the ionically bound peroxidase and some physicochemical properties are also described.

\section{MATERIALS AND METHODS}

Plant material and chemicals: Peach fruit (Prunus persica L.) cv. Rei da Conserva, grown under standard conditions in the state of São Paulo, were picked at the ripe stage, washed, peeled, cut into small pieces, stored at $-20^{\circ} \mathrm{C}$ and used for enzymes extraction. All chemicals were reagent grade. DEAE-cellulose, Sephadex G-100, polyethylene glycol 20000, L-cysteine, bovine serum albumin, soybean trypsin inhibitor, ovalbumin, lactate dehydrogenase, cytochromo $\mathrm{C}$, caffeic, ferulic, protocatechuic, pcoumaric acids, o-dianisidine, N-ethylmaleimide, $\quad \mathrm{p}$ chloromercuribenzoate (p-CMB) were obtained from Sigma Chemical Co (St Louis, MO, USA).

Storing at $20^{\circ} \mathrm{C}$ : Peach fruit were picked at mature-green stage, washed and stored at $20^{\circ} \mathrm{C}$ in a chamber with relative humidity control. The evolution of the ripening was observed by color/texture alterations and aliquots of three fruits were select at different times, peeled, cut into small pieces and used for enzymes extraction.

Enzymes extraction: Twenty-five g of tissue was homogenized in $0.1 \mathrm{M}$ potassium phosphate buffer, pH 6.5 containing $1 \mathrm{mM}$ tcysteine with addition of Polyclar aT $(0.1 \mathrm{~g} / 10 \mathrm{~g}$ of tissue $)$ as phenolic scavenger (Neves \& Lourenço, 1985). The suspension was filtered through four layers of cheescloth and centrifuged at $25000 \mathrm{~g}$ for $30 \mathrm{~min}$. The supernatant was collected (crude extract) and used to assay for soluble POD and PPO (polyphenoloxidase). The sediment fraction was resuspended in $40 \mathrm{ml}$ of the above buffer containing $1.0 \mathrm{M} \mathrm{NaCl}$, stirred mechanically for $12 \mathrm{hr}$ (overnight), and centrifuged as above. The supernatant was used as a source of ionically bound peroxidase. In some experiments, $\mathrm{NaCl}$ was replaced with $\mathrm{CaCl}_{2}$ or $\mathrm{MgCl}_{2}$. All procedures were carried out at $4^{\circ} \mathrm{C}$.

Enzyme assay: Soluble and ionically bound peroxidase activities were determined by change in absorbance at $460 \mathrm{~nm}$ due to o-dianisidine oxidation in the presence of hydrogen peroxide and the enzyme (Neves \& Lourenço, 1998). The reaction mixture consisted of $0.2 \mathrm{ml} 15 \mathrm{mM} \mathrm{O}$ dianisidine; $0.2 \mathrm{ml} 10 \mathrm{mM}$ hydrogen peroxide, 0.1 $\mathrm{M}$ potassium phosphate-citrate buffer, $\mathrm{pH} 5.0$ in a total volume of $3.0 \mathrm{ml}$. One enzyme unit is defined as the amount of enzyme producing a 0.001 absorbance change per min under the assay conditions used. The reaction mixture for PPO assay contained $6 \mathrm{mM}$ of 4-methylcatechol, citrate-phosphate buffer, $\mathrm{pH} 5.0$ and enzyme solution in a total volume of $3 \mathrm{ml}$. The reaction was initiated by the addition of the enzyme and the absorbances were automatically recorded at 420 $\mathrm{nm}$ and $30^{\circ} \mathrm{C}$. The enzyme unit was defined as cited above for POD. 
Purification: The supernatant containing the ionically bound POD after extraction was dialysed against solid PEG-20000 to concentrate the protein. After concentration, the extract was applied to a column of DEAE-cellulose (1.5 x 20 $\mathrm{cm}$ ), previously equilibrated and washed with 5 $\mathrm{mM}$ phosphate buffer, $\mathrm{pH}$ 7.0. Protein was eluted with a linear gradient of $\mathrm{KCl}(0-0.4 \mathrm{M})$ in $5 \mathrm{mM}$ potassium phosphate buffer, $\mathrm{pH} 7.0$ and $5 \mathrm{ml}$ fractions were collected. The active fractions were pooled and applied to a column of Sephadex G$100(2 \times 50 \mathrm{~cm})$ equilibrated and washed with the same buffer. The eluted fractions containing peroxidase activity were pooled and used for the studies.

Protein determination: Protein concentration of the various extracts and solutions was determined by the method of Lowry et al. (1951) using bovine serum albumin as a standard. Absorbance at $280 \mathrm{~nm}$ was used to monitor protein in the column eluates.

Effect of temperature/thermal stability: Reactions were carried out under standard assay conditions as described above at 10 to $60^{\circ} \mathrm{C}$. The Ea (apparent activation energy) for the reaction was determined by measuring the reaction rate constant at different temperatures. Thermal stability of Sephadex G-100 purified ionically bound POD as a function of temperature was determined over the range of 60 to $75^{\circ} \mathrm{C}$ using 0.1 $\mathrm{M}$ potassium phosphate buffer, $\mathrm{pH}$ 7.0. The enzyme was placed in a test tube into a water bath, pre-set at the appropriate temperatures. Aliquots of purified enzyme solutions were withdrawn at timed intervals, rapidly cooled in an ice bath and assayed for the remaining activity under the assay conditions described above. Percent residual activity was calculated as percent of the original activity in the unheated preparation. Effect of sucrose: To study the effect of sucrose on enzyme heat stability, purified POD was incubated at the temperatures in the presence of various concentrations of the sugar and the residual activity determined as cited above. The apparent activation energy (Ea) for inactivation was determined by measuring the reaction rate constant for inactivation at different temperatures in the presence and absence of sugar.

pH optimum: Enzyme activity as a function of $\mathrm{pH}$ was determined using o-dianisidine, citratephosphate buffer $(\mathrm{pH} 3.0-6.5)$ and tris- $\mathrm{HCl}$ buffer
(pH 7.0-9.0). POD activity was assayed under standard conditions as described above.

Kinetic studies: The apparent $\mathrm{K}_{\mathrm{m}}$ and $\mathrm{V}_{\text {max. }}$ were determined from Lineweaver-Burk plots at optimum $\mathrm{pH}$ and temperature conditions .

Inhibitor studies: The enzyme was incubated with varying substrate concentrations at two fixed inhibitor concentrations. The values of inhibition constant (Ki) and the type were determined by Dixon plot (1953). All assays were performed in triplicates.

Molecular weight determination: Molecular weight was determined by gel filtration on a Sephadex G-100 column. The column was calibrated for molecular weight with standard protein; cytochrome C (12400), soybean trypsin inhibitor (21500), ovalbumin (43000), bovine serum albumin (67000) and lactate dehydrogenase (130000). The Mr was estimated using a plot of $\mathrm{Ve} / \mathrm{Vo}$ vs $\log \mathrm{Mr}$ of standard proteins according to the method of Whitaker (1963).

Polyacrylamide gel electrophoresis: The PAGE was performed by the method of Davis (1964) using $7 \%$ polyacrylamide gel in tris-glycine buffer, $\mathrm{pH} 8.3$, at $4^{\circ} \mathrm{C}$ with $2.5 \mathrm{~mA}$ per tube. After the run the gels were incubated in a solution containing $0.2 \%(\mathrm{w} / \mathrm{v})$ odianisidine at $\mathrm{pH} 6.0$, followed by addition $30 \mathrm{mM} \quad \mathrm{H}_{2} \mathrm{O}_{2}$. Staining bands indicating POD activity appeared within 20 min at $37^{\circ} \mathrm{C}$ and the gels were rinsed in distilled water. Relative mobility was determined by the migration of the bromophenol marker dye.

Effect of divalent cations and other compounds: The effect of cations, phenolic compounds and sulphydryl-blocking reagents were verified by the addition of the compounds at different concentrations at the enzyme assay as described above for inhibitors.

\section{RESULTS AND DISCUSSION}

Activities of soluble, ionically bound peroxidase and polyphenoloxidase during ripening at $20^{\circ} \mathrm{C}$ are shown in Figure 1. The fruit took about 6 to 12 days to reach the ripe (edible) stage from the mature-green stage. The activity of soluble POD showed a peak followed by a decrease, returning to the level found in mature-green fruit. The 
ionically bound POD was not altered during the period, while polyphenoloxidase activity greatly increased with ripening with a little drop between 8 to 12 days. The PPO activity was 2.4 fold higher than the initial values, in contrast to the observed evolution of the browning rate of the tissue with ripening.

The total peroxidase activity has been shown to increase with ripening banana (Haard, 1977), peach (Flurkey \& Jen, 1978), apple (Gorin \& Heidema, 1976), tomato (Kokkinakis \& Brooks, 1979) and papaya (Silva et al., 1990), and gradually fell as the fruits turned from ripe to senescence stage. To solubilize of ionically bound POD the addition of various salts to the buffer were needed to release the enzyme from cell components. The effect of $\mathrm{CaCl}_{2}$ and $\mathrm{MgCl}_{2}$ on bound POD extraction were decreased with the increase in the salts concentration up to $1.0 \mathrm{M}$, however, $\mathrm{NaCl}$ demonstrated to be more effective on extraction condition at concentrations above $0.5 \mathrm{M}$.

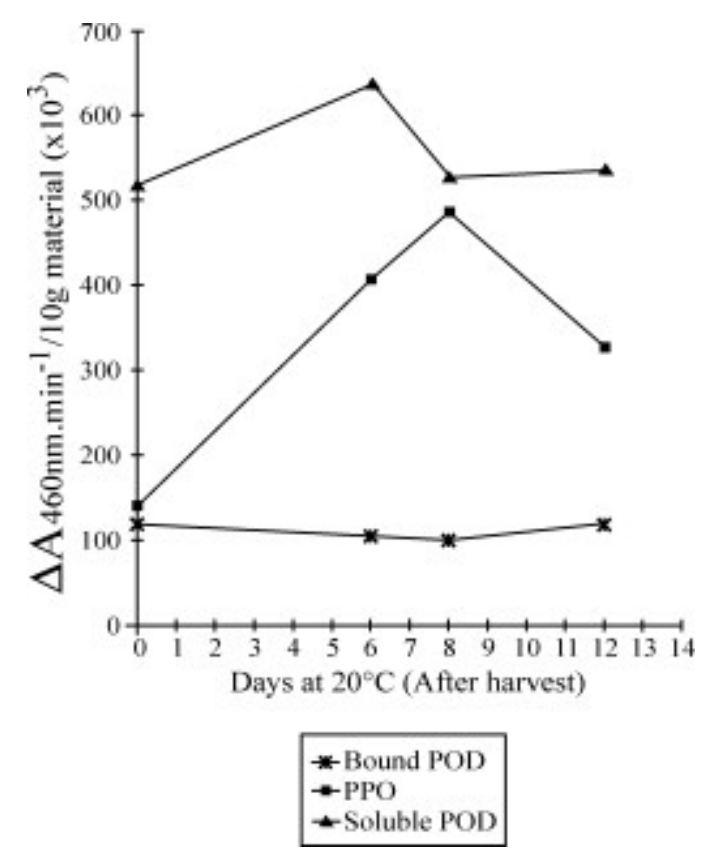

Figure 1 - Soluble, ionically bound peroxidase and polyphenoloxidase activities during the ripening of peach fruit.

Purification of ionically bound POD: Dialysis of the crude extracts against solid polyethylene glycol (PEG-20000) was most effective to concentrate. On DEAE-cellulose column $(1.5$ x 20 $\mathrm{cm}$ ), the enzyme was eluted in a single activity peak (fraction 37-44) with the wash buffer, similar to observed with the bound POD from papaya fruit by Silva et al. (1990). However, this step brought about only 2.0-fold purification. Further purification of bound peroxidase involved gel filtration on Sephadex G100 $(2.5 \times 50 \mathrm{~cm})$, which resulted in 6.1-fold purification (Table 1). The enzyme activity was eluted between fractions $56-75$, indicating the presence of only one enzyme species or more than one species of somewhat similar molecular weight (Figure 3). PAGE of this enzyme preparation revealed the presence of two bands stained for activity in the Sephadex G-100 peak (Figure 2).

\section{Properties of Sephadex G-100 purified enzyme:} Bound peroxidase activity as a function of $\mathrm{pH}$ showed a broad profile throughout the $\mathrm{pH}$ 4.56.0 range with an optimum at $\mathrm{pH}$ 5.0. The optimum $\mathrm{pH}$ of peroxidases from various vegetables sources studied occurred in the acid side of pH (Vàmos-Vigyàzo, 1981). The effect of temperature on bound peroxidase activity was studied under standard conditions. The optimum temperature was $40^{\circ} \mathrm{C}$ and $40 \%$ of the maximum activity was registered at $55^{\circ} \mathrm{C}$ indicating a heat labile enzyme. The apparent activation energy (Ea) value for product formation was found to be $10.04 \mathrm{kcal} / \mathrm{mol}$, in contrast the temperature coeficient $\left(\mathrm{Q}_{10}\right)$ calculated from this Ea value was 1.78 in the range of $20-30^{\circ} \mathrm{C}$, a similar value found for other peroxidases (Bruemmer et al., 1976, Joffe \& Ball, 1962, Neves \& Lourenço, 1998, Lourenço et al., 1995).

Thermal inactivation: Figure 4 shows the time course inactivation of purified peach ionically bound POD from 60 to $75^{\circ} \mathrm{C}$. The enzyme was reasonably stable at $60^{\circ} \mathrm{C}$ and when exposed to $65^{\circ} \mathrm{C}$, there was a $45 \%$ residual activity for $60 \mathrm{sec}$, in contrast to 30 and $15 \mathrm{sec}$ at 70 and $75{ }^{\circ} \mathrm{C}$, respectively. At $65^{\circ} \mathrm{C}$, only $20 \%$ of the residual activity was detected after $4 \mathrm{~min}$ exposure. At $70^{\circ} \mathrm{C}$, approximately $95 \%$ of the activity was lost after $3 \mathrm{~min}$ and $1 \mathrm{~min}$ at $75^{\circ} \mathrm{C}$. 
Table 1 - Purification of ionically bound peroxidase from peach.

\begin{tabular}{lcccc}
\hline Procedure & $\begin{array}{c}\text { Volume } \\
(\mathrm{ml})\end{array}$ & $\begin{array}{c}\text { Total activity } \\
\text { (units) }\end{array}$ & $\begin{array}{c}\text { Specific activity } \\
\text { (units/mg protein) }\end{array}$ & $\begin{array}{c}\text { Purification } \\
\text { (factor) }\end{array}$ \\
\hline Crude extract & 105 & $476.7 \times 10^{3}$ & 238.95 & - \\
PEG-Dialysis & 23 & $407.1 \times 10^{3}$ & 215.85 & 1 \\
DEAE-cellulose & 4.5 & $38.7 \times 10^{3}$ & 409.00 & 1.9 \\
Sephadex G-100 & 4.0 & $10.56 \times 10^{3}$ & 1320.00 & 6.1 \\
\hline
\end{tabular}
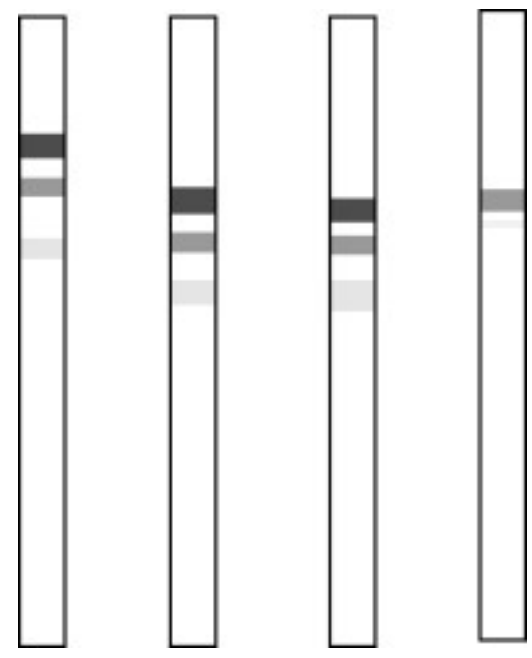

Figure 2 - Electrophoretic patterns of purified ionically bound peroxidase. (1) crude extract $(10 \mu \mathrm{g})$, (2) PEGconcentrate $(5 \mu \mathrm{g})$, (3) DEAE-ellulose (4 $\mu \mathrm{g})$, (3) Sephadex G-100 $(4 \mu \mathrm{g})$. Reactions on the gel were estimated accord to described.

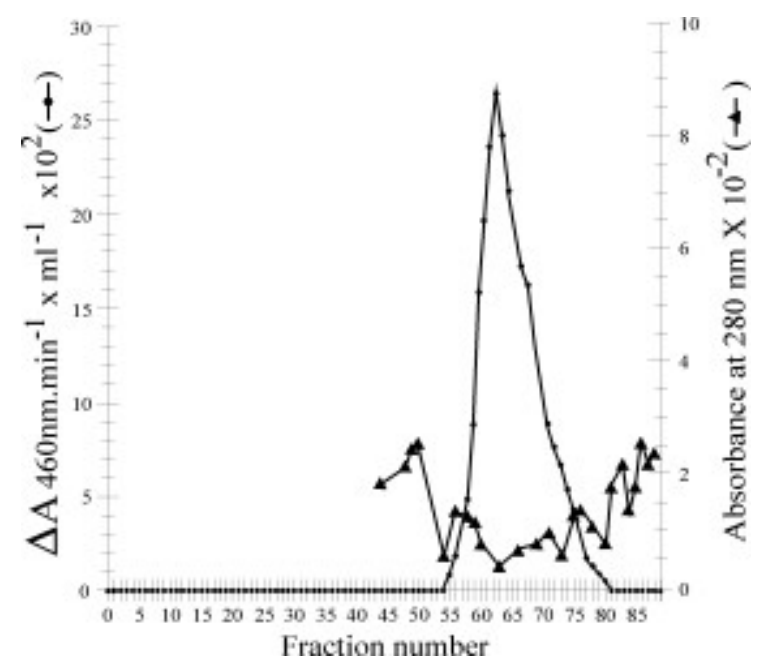

Figure 3 - Chromatography of purified ionically bound peroxidase on Sephadex G100. Enzyme solution was applied to a column of Sephadex G100 $(2 \times 50 \mathrm{~cm})$ in $\mathrm{K}-\mathrm{Pi}$ buffer, $\mathrm{pH}$ 7.5. Elution was conducted with the same buffer.
The peach bound enzyme showed a biphasic thermal inactivation behaviour only at $60^{\circ} \mathrm{C}$. However several workers impute this character non-linear to the formation during heating of denaturated protein forms and groups of POD molecule that remain actives (Lu \& Whitaker, 1974, Clemente, 1996, Khan \& Robinson, 1993, Neves \& Lourenço, 1998, Adams, J., 1997) or different conditions of the enzyme after heating (Adams, J., 1997, Clemente, 1996, McLellan \& Robinson, 1984, Hemeda \& Klein, 1991, Neves \& Lourenço, 1998). The peach peroxidases, soluble and bound, showed distinct heat lability (Neves \& Lourenço, 1998). This fact was also observed for isolated enzymes from apple (Moulding et al., 1989), papaya (Silva et al., 1990) and orange (Clemente, 1996).

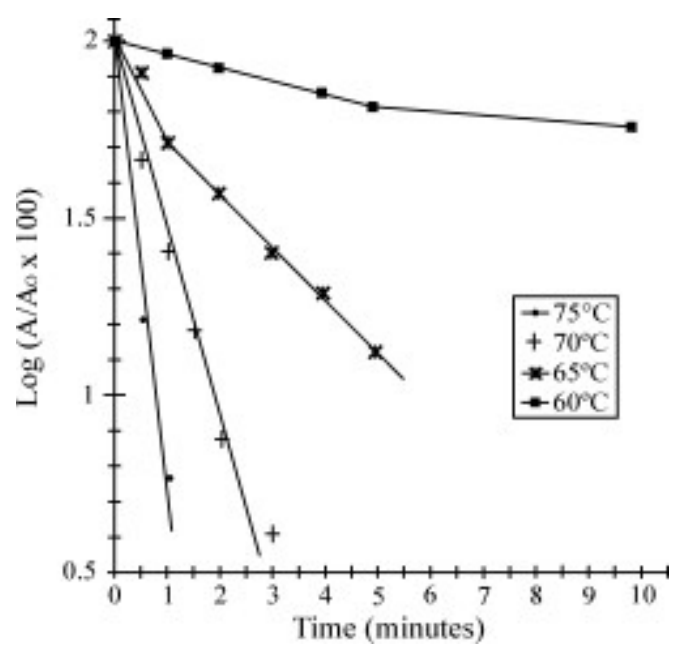

Figure 4 - Heat inactivation curves of Sephadex G-100 purified ionically bound peroxidase at $60,65,70$ and $75^{\circ} \mathrm{C}$. The residual activity was determined accord to described in Methods.

The apparent activation energy $(E a)$ for enzyme inactivation estimated from an Arrhenius plot was found to be $40.88 \mathrm{kcal} / \mathrm{mol}$. The enzyme was heated at 65,70 and $75^{\circ} \mathrm{C}$ in the presence of sucrose at 0,10 and $20 \%$ concentration in the incubation mixture. The increase in sucrose 
concentration corresponded to an increase in enzyme stability regardless of the heating temperature, when compared to control without sugar (figures 5, 6 and 7), however the stabilizing effect was more pronounced at the lower temperature. The soluble peach POD presented higher heat stability considering the same sucrose concentrations and temperatures (Neves \& Lourenço, 1998). The calculated values of the apparent activation energy $(E a)$ for enzyme inactivation in the absence and presence of sucrose at the temperature range studied revealed to increase with sugar concentration;

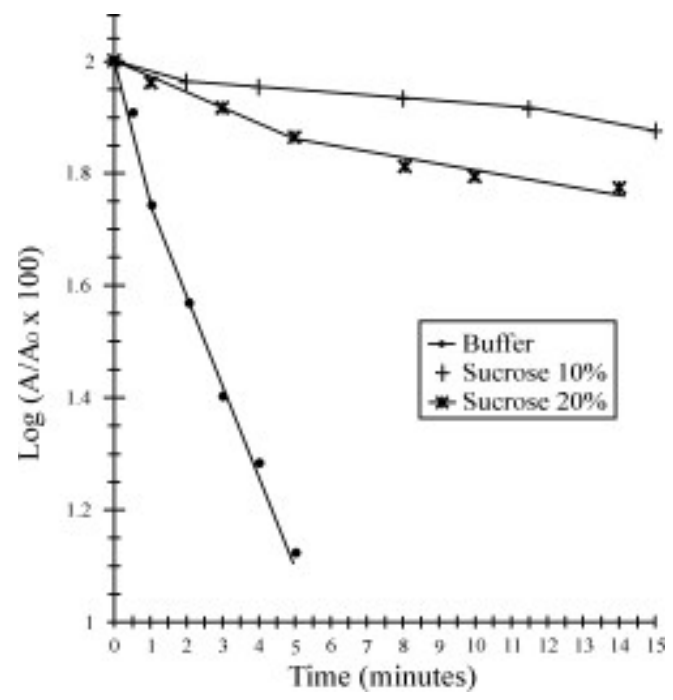

Figure 5 - Heat inactivation curves of Sephadex G-100 purified ionically bound peroxidase at $65^{\circ} \mathrm{C}$ in the presence of sucrose at 10 and $20 \%$ (w/v) concentrations. Residual activity was determined accord to described in Methods.

values of $40.88,55.30$ and $60.70 \mathrm{kcal} / \mathrm{mol}$ were found at 0,10 and $20 \%$ sucrose, respectively. The protecting effect of poliols to thermal denaturation of proteins is a fact, however the mechanisms are still in discussion (Arakawa \& Timashef, 1982, Gerisma, 1968, Frigon \& Lee, 1972, Neucere e St Angelo, 1985). Several authors observed an increase of the activation energy (Ea) for denaturation with an increase in sucrose concentration for different enzymes, and they suggested that some physicochemical properties alterations of the sistem could to be occuring, specially related to the water structure (Arakawa \& Timashef, 1982, Back et al., 1979, Lee \& Timashef, 1981). According to our results and those of other authors the enzymes from various sources behave distinctively in the presence of sugars on heating. Arakawa \& Timashef (1982) and Lee \& Timashef (1981) showed evidences of the protein-solvent relationship as a stabilizing factor of the protein structure, representing the preferential interaction protein-water as a function of the sucrose concentration in the system. To the bound POD in this study the presence of sucrose resulted in a higher stability of the protein structure whitout affecting the conformational form of the catalytic site as also

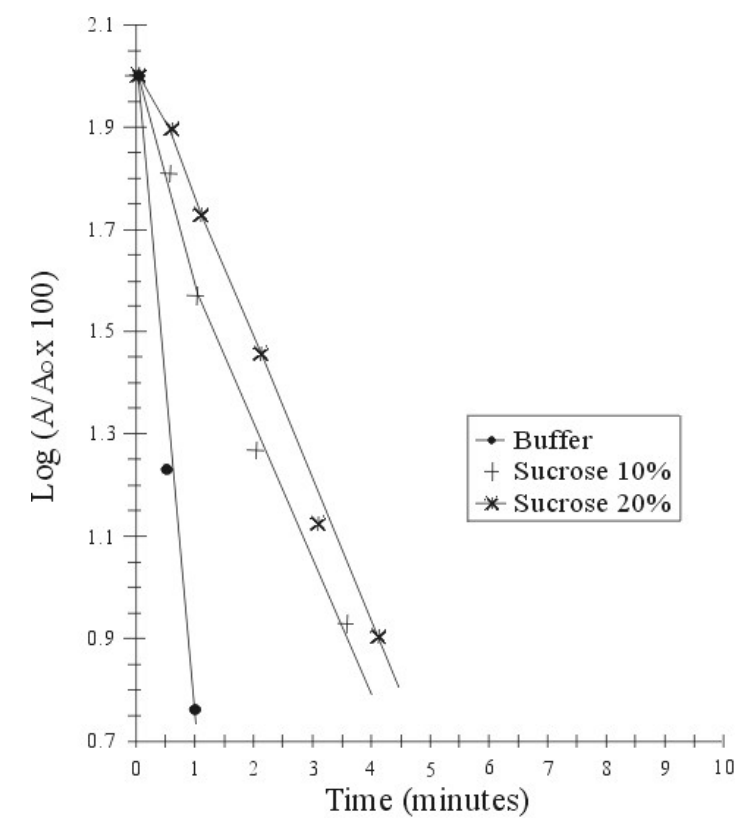

Figure 6 - Heat inactivation curves of Sephadex G-100 purified ionically bound peroxidase at $70^{\circ} \mathrm{C}$ in the presence of sucrose at 10 and $20 \%$ (w/v) concentrations. Residual activity was determined accord to described in Methods.

observed by Chang et al (1988) for horseradish peroxidase. Compared to the soluble peach POD (Neves \& Lourenço, 1998), the bound enzyme showed a reduced thermal stability compared to the same range of sucrose concentrations and temperatures studied.

Kinetic studies and molecular weight: The effect of substrate concentration on bound peroxidase was investigated. The $\mathrm{Km}$ values for o-dianisidine and hydrogen peroxide were 9.35 and $15.38 \mathrm{mM}$, respectively. The $\mathrm{V}_{\max }$ values were 1389 and $1052 \mathrm{un} / \mathrm{ml}$. The ratios $\mathrm{V}_{\max } / \mathrm{Km}$ of 148.5 and 68.6 indicated a preferential action of the enzyme for odianisidine than hydrogen peroxide. The higher specificity for the donor substrate appeared a characteristic of peroxidases from different 
sources (Silva et al., 1990, Soda et al., 1991, Vàmos- Vigyàzo, 1981). The molecular weight determination estimated by Sephadex gel filtration was calculated to be 29000 daltons, which was in agreement with the wide range of molecular weight (30-60000 $\mathrm{Da})$ reported for peroxidase from various sources (Clemente, 1996, Floris et al., 1984, Khan \& Robinson, 1993, Lourenço \& Neves, 1997, Silva et al., 1990, Vàmos-Vigyàzo, 1981).

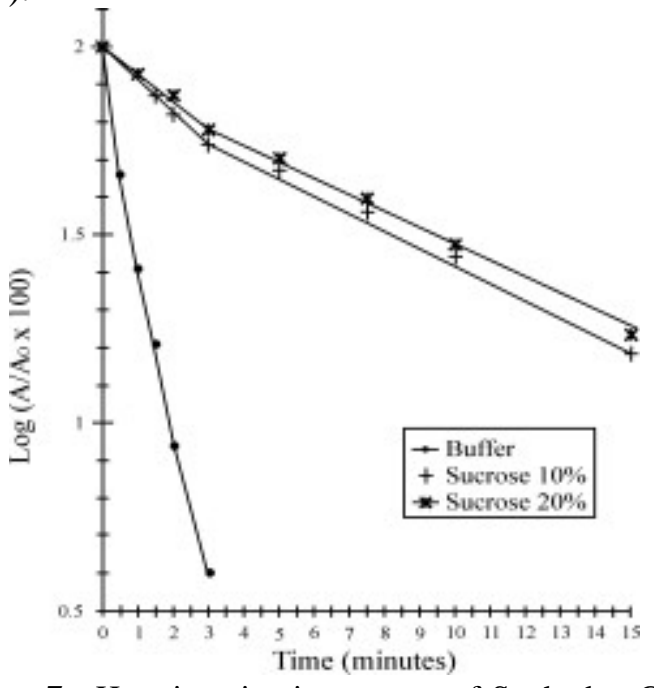

Figure 7 - Heat inactivation curves of Sephadex G-100 purified ionically bound peroxidase at $75^{\circ} \mathrm{C}$ in the presence of sucrose at 10 and $20 \% \quad(\mathrm{w} / \mathrm{v})$ concentrations. Residual activity was determined accord to described in Methods.

It is worth noting that the inhibitors had different effects on peroxidase. The following cations had no effect on the enzyme activity: $\mathrm{Zn}^{++}, \mathrm{Cu}^{++}, \mathrm{Mg}^{++}$, $\mathrm{Mn}^{++},\left(\mathrm{NH}_{4}\right)^{+}$, whereas $\mathrm{Fe}^{++}$was more effective as an inhibitor (Tables 2 and 3 ).

Table 2 - Effect of salts on Sephadex G100 purified ionically bound peroxidase*.

\begin{tabular}{lcc}
\hline \multicolumn{1}{c}{ Salt } & $\begin{array}{c}\text { Concentration in the } \\
\text { assay }(\mu \text { moles })\end{array}$ & $\begin{array}{c}\text { Inhibition } \\
(\%)\end{array}$ \\
\hline Control & - & 0 \\
$\mathrm{ZnSO}_{4}$ & 1.5 & 9.8 \\
& 6.0 & 9.8 \\
$\mathrm{CuSO}_{4}$ & 3.0 & 6.5 \\
& 6.0 & 6.5 \\
$\mathrm{MgSO}_{4}$ & 3.0 & 4.4 \\
& 6.0 & 4.4 \\
$\mathrm{MnCl}_{2}$ & 1,5 & 6.9 \\
& 6.0 & 8.0 \\
$\mathrm{FeSO}_{4}$ & 1.5 & 11.4 \\
& 3.0 & 59.40 \\
& 3.9 & 70.30 \\
\hline
\end{tabular}

*assays as described in Methods.
L-cysteine was a more potent enzyme inhibitor when compared to sulphite (Table 3). A characteristic of the 1cysteine inhibition was to exhibit a crescent lag phase with the increase of the concentration. The effect of a number of phenolic compounds on bound POD activity are shown in Tables 3 and 4 . The strongest inhibition was observed with caffeic acid, ferulic acid and protocatechuic acid followed by pcoumaric acid while indolacetic acid slightly inhibited the enzyme.

Table 3 - Effect of various compounds on Sephadex G100 purified ionically bound peroxidase*.

\begin{tabular}{lcc}
\hline Compound & $\begin{array}{c}\text { Concentration } \\
\text { in the assay } \\
(\mu \text { moles })\end{array}$ & $\begin{array}{c}\text { Inhibition } \\
(\%)\end{array}$ \\
\hline Control & - & 0 \\
L-cysteine & 0.18 & 20.83 \\
& 0.30 & 30.21 \\
$\mathrm{Na}_{2} \mathrm{SO}_{3}$ & 0.6 & 0.0 \\
& 3.0 & 16.25 \\
$\left.\mathrm{NH}_{4}\right)_{2} \mathrm{SO}_{4}$ & 6.0 & 50.00 \\
& 20 & 0.0 \\
Ferulic acid & 120 & 1.0 \\
& 0.050 & 85.0 \\
& 0.015 & 56.6 \\
Indolacetic & 0.005 & 43.3 \\
acid & 0.30 & 0.0 \\
& 0.75 & 10.0 \\
p-Coumaric & 1.50 & 45.0 \\
acid & 4.50 & 61.7 \\
& 0.30 & 8.30 \\
& 0.90 & 11.66 \\
*assays as described in Methods & 50.00
\end{tabular}

The inhibitory effects of caffeic, ferulic and protocatechuic acid were analyzed kinetically and the Dixon`s plot (1964) indicated that bound POD inhibition by these acids is a competitive type with differents $\mathrm{Ki}$ values (Table 4).

The sulphydril inhibitors p-chloromercuribenzoate and N-ethylmaleimide pratically were not effective inhibitors of bound peach peroxidase (Table 5), indicating that SH groups were not involved in ionically bound POD catalysis. 
Table 4 - Inhibitors, type and inhibition constants (Ki) for Sephadex G-100 purified ionically bound peroxidase.

\begin{tabular}{lll}
\hline \multicolumn{1}{c}{$\begin{array}{c}\text { Inhibitor } \\
\text { (acids) }\end{array}$} & $\mathrm{Ki}(\mathrm{mM})$ & Inhibition type \\
\hline Caffeic & $4 \times 10^{-3}$ & competitive \\
Ferulic & $2,2 \times 10^{-2}$ & competitive \\
Protocatechuic & $2,6 \times 10^{-1}$ & competitive
\end{tabular}

*Inhibition constants (Ki) and type were obtained according to the method od Dixon (1964).

Table 5 - Effect of sulphydryl-blocking reagents on Sephadex G-100 purified ionically bound peroxidase.

\begin{tabular}{lcc} 
Compound & $\begin{array}{c}\text { Concentration } \\
\text { in the assay } \\
(\mu \text { moles })\end{array}$ & $\begin{array}{c}\text { Inhibition } \\
(\%)\end{array}$ \\
\hline Control & - & 0 \\
N- & 0.30 & 6.25 \\
hylmaleimide & & \\
& 1.50 & 7.50 \\
p-CMB & 3.0 & 10.00 \\
& 0.30 & 0.0 \\
& 0.75 & 0.0 \\
*p-cloromercuribenzoate & 1.50 & 2.5 \\
\hline
\end{tabular}

Different workers have found the non-essentiality of $\mathrm{SH}$ groups for catalysis in peroxidases of distinct sources (Lourenço \& Neves, 1997, Floris et al., 1984).

\section{ACKNOWLEDGEMENTS}

This research was supported by the Faculty of Pharmaceutical Sciences-UNESP Research Commission Program (PADC-FCF-UNESP) Grant $n^{\circ} 57 / 97$.

\section{RESUMO}

As peroxidases solúvel, ionicamente ligada e a polifenoloxidase de pêsssego foram acompanhadas durante o armazenamento a $20^{\circ} \mathrm{C}$. A forma ionicamente ligada foi purificada 6,1 vezes utilizando-se de cromatografias de DEAE-celulose e Sephadex G-100. A enzima purificada foi eluída em um único pico de atividade na cromatografia de Sephadex G-100 e a eletroforese em gel de poliacrilamida (PAGE) revelou uma enzima purificada pelos procedimentos adotados. A enzima purificada apresentou um peso molecular de $29000 \mathrm{Da}, \mathrm{pH}$ e temperatura ótimos de $\mathrm{pH}$ 5,0 e $40^{\circ} \mathrm{C}$. $\mathrm{O}$ valor da energia de ativação da reação foi de $10,04 \mathrm{kcal} / \mathrm{mol}$. A enzima apresentou-se termolábil na faixa entre $60-75^{\circ} \mathrm{C}$ com rápida inativação a $75^{\circ} \mathrm{C}$. Medida da atividade residual mostrou um efeito estabilizante da sacarose a várias temperaturas e concentrações do açucar $(0$, 10 e $20 \%, \mathrm{p} / \mathrm{v}$ ) com uma energia de ativação (Ea) para inativação crescente com a concentração de sacarose. As constantes cinéticas Km e Vmax foram calculadas para odianisidina e peróxido de hidrogenio. A enzima ligada foi inibida competitivamente por ácido ferúlico, cafeico e protocatéquico com valores distintos de Ki. Lcisteína, ácidos pcumárico e indolacéico e $\mathrm{Fe}^{++}$, inibiram a enzima porém em menor intensidade. N-etilmaleimida e $\quad$ p-CMB (pcloromercuribenzoato) não foram eficientes na inibição enzimática.

\section{REFERENCES}

Abeles, F. B. and Biles, C. L. (1991), Characterization of peroxidase in lignifying peach fruit endocarp. Plant Physiology. 95, 269-273.

Adams, J. (1997), Regeneration and kinetics of peroxidase inactivation. Food Chem., 60, 201-206.

Arakawa, T. and Timashef, S. N. (1982), Stability of protein structure by sugars. Biochemistry. 21, 6536-6544.

Back, J. F.; Oakenful, O. and Smith, M. B. (1979), Increased thermastability of proteins in the presence of sugars and polyols. Biochemistry. 18, 5191-00.

Bradbury, S. L. and Jacoby, W. B. (1972), Glycerol as an enzyme-stabilizing agent: Effects on aldeydedehydrogenase. Proc Natl. Acad. Sci. USA., 69, 2373.

Bruemmer, J. H.; Roe, B. and Bower, E. R. (1976), Peroxidase reactions and orange juice quality. $J$. Food Sci. 141, 186-9.

Burnette, F. S. (1977), Peroxidase and its relation to food flavor and quality. A review. J. Food Sci. 4, 1-6.

Chang, B. S.; Park, K. H and Lund, D. B. (1988), Thermal inactivation kinetics of horseradish peroxidase. J. Food Sci. 53, 920-23.

Clemente, E. (1996), Isolamento, purificação e termoestabilidade da isoperoxidase do suco de laranja. Ciênc. Tecnol. Aliment. 16, 1-5. 
Clemente, E. and Pastore, G.M. (1998), Peroxidase and polyphenoloxidase, The importance for Food Technology. Bol. Soc. Brasil. Cienc. Tecnol. Aliment. 32 (2), 167-71.

Davis, B. J. (1964), Disk electrophoresis. II. Method and application to human serum protein. Annals New York Acad. Sci. 121, 404-27.

Dixon, M. (1953), The determination of enzyme inhibition constants. Biochem. J. 121,.404-27.

Floris, G.; Medda, R. and Rinaldi, A. (1984), Peroxidase from Ipomoea batatas seedlings: Purification and properties. Phytochemistry. 23, 1523-29.

Flurkey, W. H. and Jen, J. J. (1978), Peroxidase and polyphenoloxidase activities in developing peaches. J. Food Sci. 43, 1826-28.

Frigon, R. P. and Lee, J. C (1972), The stabilization of calf-brain microtubule by sucrose. Arch. Biochem. Bioph. 153, 587.

Gerisma, S. Y. (1968), Reversible denaturation of ribocuclease in aqueous solutions as influenced by polyhydric alchool and some other additives. J. Biol. Chem. 243, 957.

Gillikin, J. W. and Graham, J. S. (1991), Purification and developmental analysis of the major anionic peroxidase from the seed coat of Glycine max. Plant Physiology. 96, 214-220.

Gorin, N. and Heidema, F. T. (1976), Peroxidase activity in Golden Delicious apples as a possible parameter of ripening and senescence. J. Agric. Food Chem. 24, 200-01.

Haard, N. F. (1973), Upsurge of particulate peroxidase in ripening banana fruit. Phytochemistry. 12, 555-60.

Haard, N. F. (1977), Physiological roles of peroxidase in posharvest fruits and vegetables. In-Enzymes in food and beverages processing, eds. Ory, R.L. \& St. Angelo, A. J. ACS; pp.143.

Hammerschmidt, R., Lamport, D.T.A. and Muldoon, E.P. (1984), Cell wall hydroxyproline enhancement and lignin deposition as an early event in the resistance of cucumber to Cladosporium cucumerium. Physiol. Plant Pathol. 24, 43-47.

Hemeda, H. M. and Klein, B. (1991), Inactivation and regeneration of peroxidase activity in vegetables extracts treated with antioxidants. J. Food Sci. 56, 68-72.

Joffe, F. M. and Ball, C. O. (1962), Kinetics and energetics of thermal inactivation and reactivation of horseradish peroxidase. J. Food Sci. 27, 587-92.

Khan, A. A. and Robinson, D. S. (1993a), Purification of anionic peroxidase isoenzyme from mango (Mangifera indica L. var. Chaunsa), Food Chem. 46, 61-64.

Khan, A. A. and Robinson, D. S. (1993b), The thermostability of purified mango isoperoxidases. Food Chem., 47, 53-59.
Kokkinakis, D. M. and Brooks, J. L. (1979), Tomato peroxidase: purification, characterization and catalytic properties. Plant Physiol. 63, 93-99.

Lee, J. C. and Timashef, S. N. (1981), The stabilization of proteins by sucrose. J. Biol. Chem., 256, 7193-201.

Lourenço, E. J; Neves, V. A., and Silva, M. A. (1995), Heat inactivation of soluble and bound peroxidase from papaya fruit. Bol. Soc. Brasil. Cienc. Tecnol. Alim. 29 (2), 155-58.

Lourenço, E. J. and Neves, V. A. (1997), Peroxidase solúvel de pêssego: purificação parcial e propriedades. Ciênc. Tecnol. Aliment. 17, 42-48.

Lowry, O. H.; Rosebrough, N. J.; Farr, A. L. and Randall, R. J. (1951), Protein Measurement with the Phenol reagent. J. Biol. Chem. 193, 265-75.

Lu, A. T. and Whitaker, J. R. (1974), Some factors affecting rates of heat inactivation and reactivation of horseradish peroxidase. J. Food. Sci. 39, 1173-77.

McLellan, J. M. and Robinson, D. S. (1984), Heat stability of peroxidase from orange. Food Chem. 13, 139-47.

Miesle, T. J.; Proctor, A. and Lagrimini, L. M. (1991), Peroxidase activity isoenzymes, and tissues localization in developing highbush bluberry fruit. $J$. Amer. Soc. Hortic. Sci. 116, 827-30.

Moulding, P. H.; Grant, H. F.; McLellan, K. M. and Robinson, D. S. (1987), Heat stability of soluble and ionically bound peroxidases extracted from apples. Intern. J. Food Sci. Technol. 22, 391-97.

Moulding, P. H.; Goodfellow, J.; McLellan, K. M. and Robinson, D. S. (1989), The occurence of isoperoxidases in conference pears. Intern. J. Food Sci. Technol., 24, 269-75.

Neucere, N. J. and St Angelo, A. J. (1985), Physicochemical properties of peanut protein in sucrose. Anal. Biochem. 47, 80-89.

Neves, V. A. and Lourenço, E. J. (1985), Extração e atividade da peroxidase e polifenoloxidase de batatadoce (Ipomoea batatas Lam.) Rev. Cienc. Farmac. 7, 101-107.

Neves, V. A. and Lourenço, E. J. (1998), Peroxidase from peach fruit: Thermal stability. Braz. Arch. Biol. Technol., 41 (2), 179-186.

Rhotan, C. and Nicholas, J. (1989), Changes in acidic and basic peroxidase activities during tomato fruit ripening. Hortic. Sci., 24, 340-2.

Robinson, D. S.; Bretheric, M. R. and Donnelly, J. (1989), The heat stability and isoenzyme composition of peroxidase in Ohane grapes. Int. J. Food Sci. Technol., 24, 613-18.

Silva, E.; Lourenço, E. J. and Neves, V. A. (1990), Soluble and bound peroxidase from papaya fruit. Phytochemistry. 29, 1051-6.

Soda, I.; Hasegawa, T.; Suzuki, T. and Ogura, N. (1991), Purification and some properties of peroxidase from kiwifruit. Agric. Biol. Chem. 55, $1677-8$. 
Thomaz, R. L.; Jen, J. J.and Morr, C. V. (1981), and Changes in soluble and bound peroxidase-IAA oxidase during tomato fruit development. J. Food Sci., 47, 158-61.

Vàmos-Vigyàzo, L. (1981), Polyphenoloxidase and peroxidase in fruit and vegetables. CRC Crit. Rev. Food Sci. Nutr., 15, 49-127.

Wang, Z. and Luh, B. S. (1983), Characterization of soluble and bound peroxidases in green asparagus. $J$. Food Sci. 48, 1412-21.
Whitaker, J. R. (1963), Determination of molecular weights of proteins by gel filtration on Sephadex. Anal. Chem. 35, 1950-53.

Received: April 25, 2000; Revised: October 31, 2000; Accepted: February 22, 2001. 